\title{
Comparison of Heart Type Free Fatty Acid Binding Protein, CPK-MB and Troponin-I in the Early Diagnosis of Acute Coronary Syndrome
}

\author{
Akut Koroner Sendromun Erken Tanısında Kalp Tipi Serbest Yağ Asidi Bağlayıcı Proteinin, \\ CPK-MB ve Troponin-l'in Karșılaștırılması
}

\author{
Mehmet Burak Aktuğlu, Onur Tunca, Eray Atalay, Șencan Acar, Sadrettin Özge Erez, Namık Yiğit, \\ Mesut Ayer, Zeynep Karaali, Taner Alioğlu \\ Turkish Ministery of Health, Haseki Research and Education Hospital, Department of Internal Medicine, Istanbul
}

\begin{abstract}
AIM: Heart type free fatty acid binding protein $(H-F A B P)$ is a new marker of myocyte damage used in the early diagnosis (within the first two hours) of acute myocardial infarction (AMI). The aim of our study was to evaluate the cardio-sensitivity and specificity of $H-F A B P$ during the acute phase of the AMI in comparison with creatinine phsphokinase- $m$ band (CPK-MB) and troponin-I.
\end{abstract}

METHODS: Patients diagnosed with acute coronary syndrome $(n=41)$ and chest pains of non cardiac origin $(n=38)$ were included. All participants had symptoms lasting not more than 12 hours. At the time of hospital admission blood samples were obtained in order to determine the serum levels of H-FABP, CPK-MB and Troponin-l.

H-FABP levels were measured by using Hycult biotech HK 401 Human H-FABP Elisa kits and the sandwich method. CPK-MB and Troponin-I levels were measured in Liaison Diasorin apareil with the principle of chemiluminescent microparticle immunoassay.

Beside the comparison of the data obtained from both groups, a ROC curve analysis was performed to define the sensitivity and specificity of the measurement of the H-FABP levels to diagnose the acute coronary syndrome.

RESULTS: The parameters of gender, age, and smoking did not differ between the study and the control groups. Serum levels of diagnostic cardiac markers of acute coronary syndrome including CPK-MB, Troponin-I and H-FABP were significantly higher in the study group $(p<0.05)$. In addition, serum very low density lipoprotein (VLDL), low density lipoprotein ( $L D L$ ) and total cholesterol levels were significantly higher in the study group in comparison to the control group $(p<0.05)$.

Area under the curve was measured larger for H-FABP at all studied time intervals in comparison with the AUC measured for CPK$M B$ and Troponin-I $(p<0.05)$.

CONCLUSION: H-FABP may be detected in the blood samples of patients diagnosed with acute coronary syndrome by using the

Mehmet Burak, Aktuğlu, Haseki Ë̆itim ve Arastrrma Hastanesi, Aksarav, Istanbul, Türkiye, Tel.0212 5294400-1503 Email.lifeiner@yahoo.com Gelis Taribi: 17.10.2012 • Kabul Taribi: 19.10.2012 appropriate and sensitive laboratory testing methods and it may be used as an alternative diagnostic tool instead of the traditional markers.

Key words: acute coronary sydrome; early diagnosis; H-FABP; creatine kinase; MB form; troponin; ROC curve

\section{ÖZET}

AMAÇ: Kalp tipi serbest yağ asidi bağlayıcı protein (H-FABP) akut myokard infarktüsünün (AMI) erken dönem (ilk iki saat) tanısında kullanılan ve myosit hasarını gösteren yeni bir belirteçdir. Bu açlıșmanın amacı H-FABP'nin kardiyak duyarılığını ve özgüllüğünü, kreatinin fosfokinaz (CPK-MB) ve Troponin-I ile karșılaștırarak tanımlamaktır.

YÖNTEM: Bu çalıșmada akut koroner sendromu ( $n=41)$ ve kalp dıșı sebeple göğüs ağrısı =n=38) olan hastalar yer aldı. Bütün katılımcllarda belirtiler 12 saatten daha az süredir vardı. Hastaneye bașvuru sırasında H-FABP, CPK-MB and Troponin-I serum seviyelerini belirlemek için kan örnekleri alındl.

H-FBP seviyeleri Hycult biotech HK 401 Human H-FABP Elisa kitleri kullanılarak sandwich yöntemiyle ölçüldü.CPK-MB ve Troponin-l seviyeleri Liaison Diasorin apareil ile kemoillümünasyon mikropartikül tekniği kullanılarak ölçüldü.

Her iki gruptan da elde edilen verilerin karșılaștııımasının yanında, H-FABP'nin akut koroner sendromu tanımadaki özgüllük ve duyarlılığını belirlemek için ROC eğrisi analizi yapıldı.

BULGULAR: Yaș, cinsiyet ve sigara alıșkanlığı açısından gruplar arası belirgin farkllık izlenmedi. Akut koroner sendrom için tanısal olan markerlerden H-FABP, CPK-MB ve Troponin-I çalıșma grubunda anlamlı olarak yüksek bulundu. Ek olarak, çok düșük ağırlıklı lipoprotein, düșük ağırlıkı lipoprotein ve total kolesterol seviyeleri de kontrol grubuna gore çalıșma grubunda anlamlı olarak daha yüksekti ( $p<0.05)$.

Eğri altında kalan alan ölçümü H-FABP için, çalıșmanın her evresinde $C P K-M B$ ve Troponin-I için ölçülen alandan daha fazla ölçüldü $(p<0.05)$.

SONUÇ: H-FABP, akut koroner sendromlu hastaların kan örneklerinden uygun ve hassas laboratuvar testleri kullanılarak saptanabilir ve geleneksel belirteçlerin yerine alternative bir tanısal araç olarak kullanılabilir.

Anahtar kelimeler: Akut koroner sendrom; erken tanl; H-FABP; kreatinin kinaz; $M B$ formu; troponin; ROC eğrisi 


\section{Introduction}

Chest pain constitutes the $50 \%$ of the symptoms resulting in an emergency admittance and $25 \%$ of the admitting patients are internalized ${ }^{1}$. Frequently, the chest pain is the unique symptom of the acute coronary syndrome. In a study evaluating the outcomes of the patients admitted to the emergency department with chest pain, the rates of the final diagnoses of AMI, unstable angina pectoris (USAP) and non cardiac chest pain were $1 / 3,1 / 3$ and $1 / 3$, respectively ${ }^{2}$.

Acute coronary syndrome may manifest with a series of clinical syndromes including ST segment elevation Myocardial infarction (STEMI), NON ST elevation myocardial infarction (NSTEMI) and USAP. These life threatening clinical syndromes are serious and should be diagnosed and treated immediately ${ }^{3,4}$.

All around the world AMI is the leading cause of death. In western countries half of the deaths are due to the cardiovascular diseases and $75 \%$ of them are related to coronary artery diseases ${ }^{5}$.

In one-third of the AMIs, there is not a clinical symptom. Electrocardiographic examination fails in diagnosis during the first attendance ${ }^{3,4}$. Uncertainty and delays in diagnosis lead to the improper management options and may delay initiation of life-saving treatments.

In 2000, European Society of Cardiology (ESC) and American College of Cardiology (ACC) redefined AMI. According to both societies, AMI is diagnosed in case when CPK-MB and/or Troponin-I (TN-I) level(s) elevations are associated with the concordant symptoms or ECG alterations.

The routine use of modern biomarkers significantly enabled the evaluation of myocardial damage. Following the use of new markers, $1 / 3$ of patients who had previously diagnosed with USAP were revaluated as having a "myocardial damage"

Heart type free fatty acid binding protein (H-FABP) is a recently discovered cardiac biomarker. It is a low molecular weight $(\mathrm{LMW}=15-16 \mathrm{kDa})$ cytosolic protein specific to cadiomyocyte and plays an important role in the intracellular-transport of the fatty acids for B-oxidation in mitochondrias ${ }^{7,8}$.

H-FABP reflects the sarcolemmal change during acute myocardial ischemia. Plasma kinetics and secretion of $\mathrm{H}-\mathrm{FABF}$ is similar to myoglobin, thus it is valuated as a marker in the early diagnosis of AMI (in the first 2 hours) ${ }^{9}$. There are remarkable numbers of studies for the valuation of H-FABP in NSTEMI, but only a few in STEMI.

High myocardial tissue content, intra-cytosolic domination, low molecular weight, relative tissue specificity and early demonstrability in urine and blood after the initiation of AMI (within the first two hours) construct the rationality for the use of H-FABP in the early diagnosis of acute coronary syndrome ${ }^{10}$. H-FABP concentration in myocardial muscle is higher than in skeletal muscle in comparison to myoglobin. In addition its basal concentration is lower than the basal concentration of myoglobin. This feature makes H-FABP superior to myoglobin for diagnostic use ${ }^{11-13}$.

In this study we aimed to evaluate the diagnostic effectiveness of $\mathrm{H}-\mathrm{FABF}$ in the early diagnosis of the acute coronary syndrome in comparison to CPK-MB and Troponin-I.

\section{Methods}

This prospective study was performed in Haseki Research and Education Hospital of Turkish Ministry of Health. During patient care, clinical evaluation and performing the study we obeyed the statement of Helsinki Declaration.

The study group included 41 patients diagnosed with acute coronary syndrome regarding to the specific ECG changes, demonstration of the cardiac markers and chest pain with an onset within the last 12 hours before admission to the emergency unit of the hospital. The control group included 38 patients with a symptom of chest pain of non cardiac origin. The non cardiac origin of the chest pain was considered regarding to the continuous normal ECG findings and cardiac marker levels.

Patients younger than 15, and admitted to hospital and treated within the last one week with a symptom of chest pain were excluded. Renal failure, previous angiography-by pass- stent or open heart surgery, depression or somatization disorder, chronic obstructive pulmonary disease, cerebro-vascular accident (recent or current), acute mesenteric artery disease, multi organ failure, serious hemodynamic disturbances and unwillingness to participate in the study also caused exclusion.

Data including the demographics and past medical history such as age, gender, systemic diseases, coronary risk factors and routine use of medications were recorded. All participants were evaluated by using ECG 
tracings, and the serum levels of cardiac enzymes, lipids and the basic routine biochemical parameters.

H-FABP levels were measured by using Hycult biotech HK 401 Human H-FABP Elisa kits and the sandwich method. CPK-MB and Troponin-I levels were measured in Liaison Diasorin apareil with the principle of chemiluminescent microparticle immunoassay. The study groups were compared by using the recorded data and the serum H-FABP levels.

Coronary artery risk factors were isolated according to the 3rd adult treatment panel (ATP III) of National Cholesterol Education Program (NCEP) and the Turkish Society of Cardiology's coronary heart disease prevention and treatment guide.

SPSS version 14.0 statistical package program for windows was used for statistical analysis. During the comparison of the study and control groups, Student $\mathrm{t}$ test was used for continuous variables with normal distribution. Between group categorical variables or variables with non normal distribution were analyzed by using Mann Whitney or chi-square (or Fischer's) tests, appropriately. A ROC curve analysis was performed to define the sensitivity and specificity of the measurement of the H-FABP levels to diagnose the acute coronary syndrome. The specificity and sensitivity of H-FABP, CPK-MB and Troponin-I were evaluated for the time intervals depending on the onset of the symptoms as between $0-4,4-12$ and $0-12$ hours by using the analysis of area under the curve (AUC). A p value of $<0.05$ was considered significant.

\section{Results}

The data dealing with the parameters of gender, age, and smoking did not differ between the study and the control groups with $p$ values of $0.732,0.299$ and 0.082 , respectively $(\mathrm{p}>0.05)$.

The symptoms during hospital admission were not significantly different between groups $(\mathrm{p}>0.05)$, however hypertension and hyperlipidemia were more frequent in the study group $(\mathrm{p}<0.05)$. Other than the more frequent use of $\beta$-blockers in the study group $(\mathrm{p}<0.05)$, previously used medications (Table 1$)$ were not significantly different in both groups $(\mathrm{p}>0.05)$.

Table 1. Comparison of the previous medications of the patients in both groups

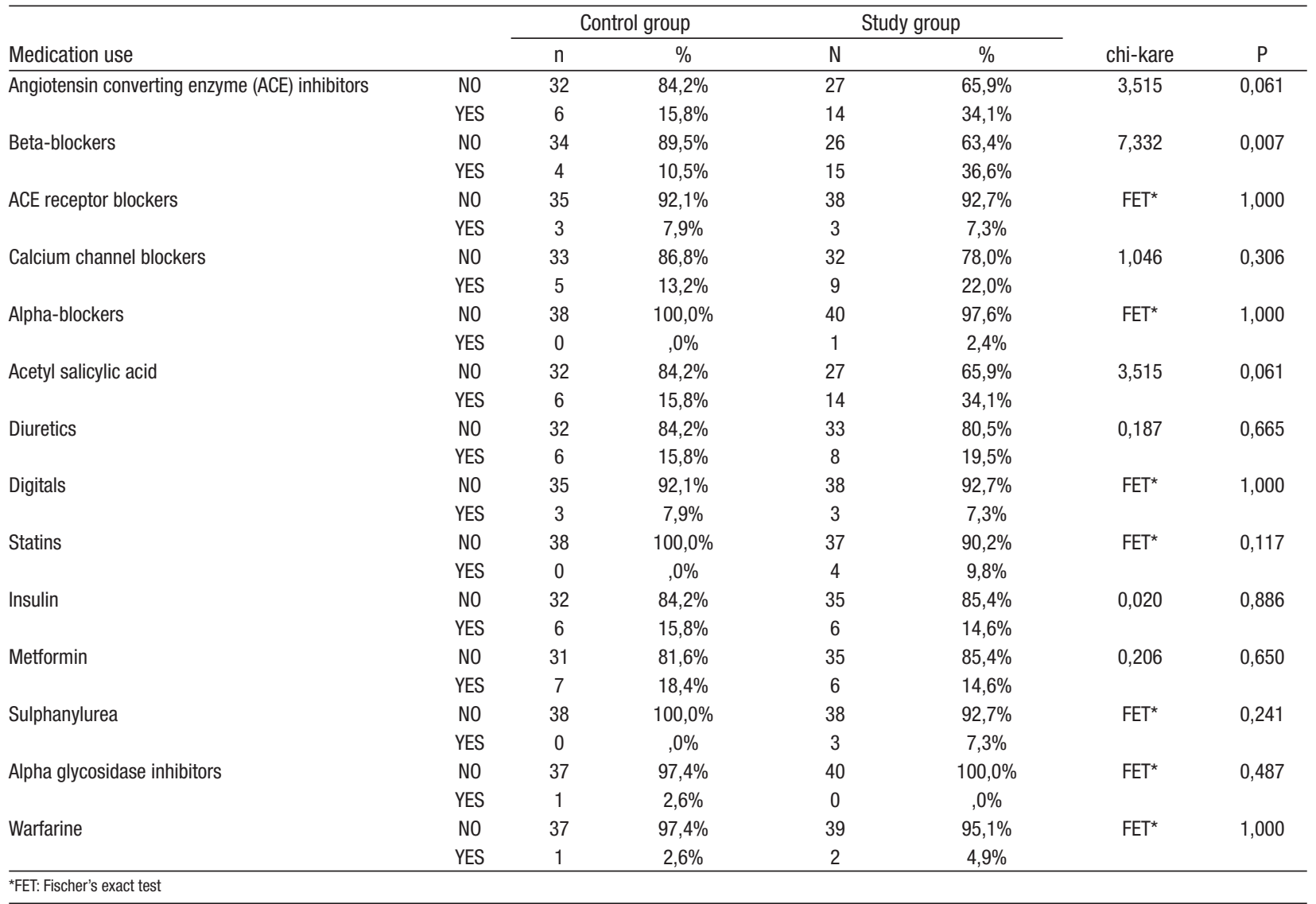


Serum levels of diagnostic cardiac markers of acute coronary syndrome including CPK-MB, Troponin-I and $\mathrm{H}-\mathrm{FABP}$ were significantly higher in the study group $(\mathrm{p}<0.05)$. In addition, serum very low density lipoprotein (VLDL), low density lipoprotein (LDL) and total cholesterol levels were significantly higher in the study group in comparison to the control group $(\mathrm{p}<0.05)$.

Area under the curve was measured larger for H-FABP at all studied time intervals (Graph 1-3) in comparison with the AUC measured for CPK-MB and Troponin-I $(\mathrm{p}<0.05)$. Table 2 summarizes the achieved values for the AUC analysis of the three markers.

\section{Discussion}

Depending to the findings of our study H-FABP with high sensitivity and specificity rates is a useful marker for the earlier diagnosis of acute coronary syndrome and the routine use of it may increase the rates of early diagnosis.

H-FABP measurements in the evaluation of patients admitted to the emergency units with a symptom of chest pain are not well studied. In this manner our study may aid in the collection of the data dealing with the issue. However, our study reflects results of a single center and the validation of the H-FABP is based on the clinical evaluation of the acute coronary syndrome. In addition, the sensitivity and the specificity analysis were based on the clinical diagnosis which was also affected by the measurements of the other markers, CKP-MB and Troponin-I. More objective diagnostic tools such as myocardial scintigraphy and angiography are lacking in our study.

Our study is not a randomized study and the absence of a power analysis necessitates further randomized studies including larger series.

Acute myocardial infarction as the major cause of death is frequently associated with hypertension and hyperlipemia ${ }^{10,14-18}$. Similarly, in our study patients diagnosed with acute coronary syndrome had significant associations with hypertension $(n=26,63 \%)$ and hyperlipemia $(\mathrm{n}=25,61 \%)$.

Although it has not taken its place in routine clinical management of acute myocardial infarction yet, its adjunction to the routinely used cardiac markers may present H-FABP as a new cardiac marker in the early diagnosis of acute myocardial infarction ${ }^{19}$. It is a cytoplasmic protein derived from the damaged

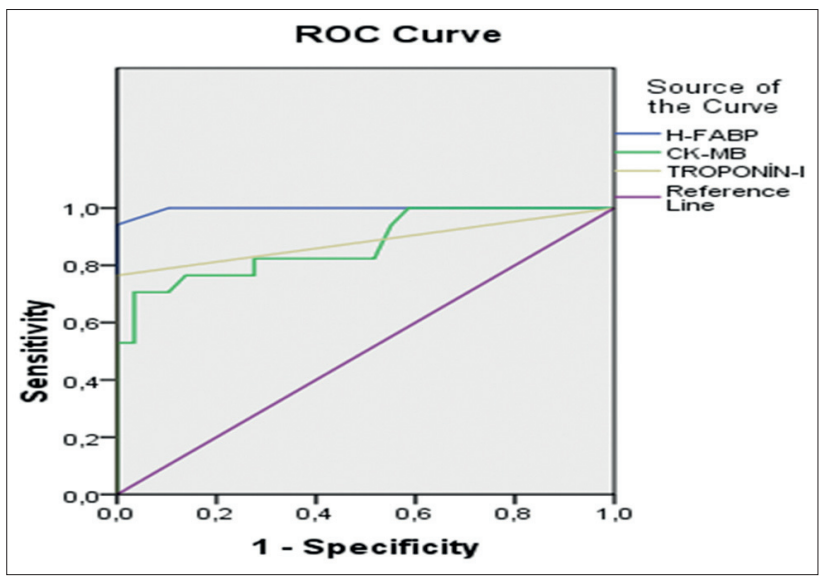

Graph 1. Receiver operator characteristic (ROC) curve analysis of H-FABP, CPK-MB and Troponin in the diagnosis of the acute coronary syndrome between 0-4 hours.

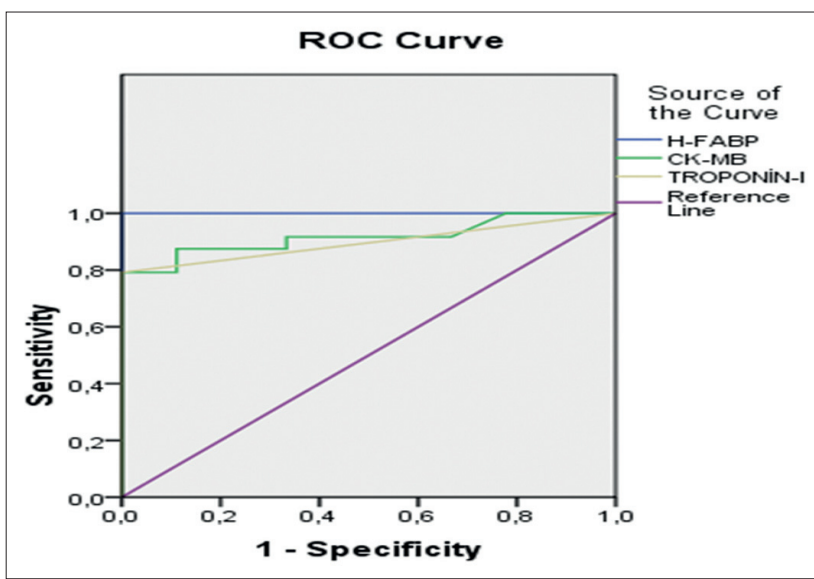

Graph 2. Receiver operator characteristic (ROC) curve analysis of H-FABP, CPK-MB and Troponin in the diagnosis of the acute coronary syndrome between 4-12 hours.

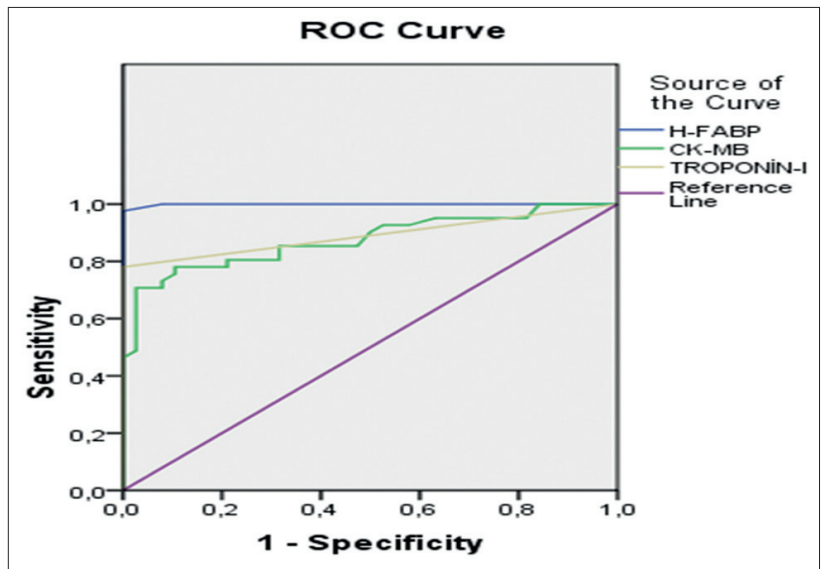

Graph 3. Receiver operator characteristic (ROC) curve analysis of H-FABP, CPK-MB and Troponin in the diagnosis of the acute coronary syndrome between 0-12 hours.

Table 2. ROC curve dispersion of the three cardiac markers at different time intervals.

\begin{tabular}{lccc}
\hline Area under the curve & $0-4$ hours & $4-12$ hours & $0-12$ hours \\
\hline H-FABP & 0,997 & 1,000 & 0,999 \\
CK-MB & 0,874 & 0,917 & 0,875 \\
TROPONIN-I & 0,882 & 0,896 & 0,890 \\
\hline
\end{tabular}


myocardial cells and has variable plasma and serum level ranges depending on the method used for its measurement ${ }^{20}$. Tanaka et al. ${ }^{21}$ and Wodzig et al. ${ }^{22}$ demonstrated the normal ranges between 0.0-0.2 $\mu \mathrm{g} / \mathrm{lt}$ and $0.3-5 \mu \mathrm{g} / \mathrm{lt}$, respectively. Similarly, in our study the normal levels of H-FABP ranged between $0.24-2.55 \mathrm{ng} / \mathrm{ml}$.

The sensitivity of a diagnostic test is far more important in emergency cases and life threatening conditions such as acute myocardial infarction. Mair et al. ${ }^{23}$ studied the sensitivity of CPK-MB in the first $3^{\text {rd }}$, $4^{\text {th }}$ and $5^{\text {th }}$ hours of acute myocardial infarction and found a sensitivity of approximately $50 \%$. Keffer et al. ${ }^{24}$ found that the sensitivity of CPK-MB was higher than the sensitivity of Troponin-I in the first 2 to 5 hours of cardiac damage. In our study, in the first 0-4 hours, the sensitivity and the specificity of H-FABP were $99 \%$ and $99 \%$, respectively. The sensitivity and the specificity rates in the same patient group for CPK- MB were $70.59 \%$ and $89.66 \%$, respectively.

Seino et al. ${ }^{25}$ found the sensitivity of H-FABP $89 \%$ in the first 2 hours of the myocardial infarction. AUC analysis of the H-FABP in 0-4 hours of our study revealed a larger area $(s=0.997)$ which may be resulted from studying a longer time period after the onset of the symptoms.

The sensitivity and specificity of H-FABP, CPK$\mathrm{MB}$ and Troponin-I were 97.6 and 88.5\%, 97.6 and $88.5 \%$, and $100 \%$ and $88.5 \%$ in the study performed by Cavus et al ${ }^{19}$, respectively. In our study the sensitivity and specificity of H-FABP, CPK-MB and Troponin-I between the $4^{\text {th }}$ and $8^{\text {th }}$ hours of acute myocardial infarction were 100 and 99\%, 70.8 and $100 \%$, and 100 and $100 \%$, respectively.

The discordance among the results of the previous studies and the current study may originate from the variable methodology and patient population encountered in the studies. Although the quality of the evidences provided from these studies seems poor, they provide a clue for further studies. Further randomized studies are needed to evaluate the exact role of H-FABP in the diagnosis of acute myocardial infarction.

In conclusion H-FABP may be detected in the blood samples of patients diagnosed with acute coronary syndrome by using the appropriate and sensitive laboratory testing methods and it may be used as an alternative diagnostic tool instead of the traditional markers.
Conflict of interest: None declared.

\section{References}

1. Hodgson L. Cost containment in the emergency department. CAL/ACEP source guide 1998; 710:23.

2. Hargarten K, Chapman PD, Stueven HA et al. Prehospital prophylactic lidocaine does not favorably affect outcome in patients with chest pain. Ann Emerg Med 1990; 19:1274-9.

3. Antman EM, Braunwald E. Acute moycardial infarction In: Braunwald E, Zipes D, Libby P, eds. Heart Disease. Ed: A textbook of cardiovascular medicine. Philadelphia: WB Saunders company 2001:1131-5.

4. Newby LK, Gibler B, Chriztenson RH, Serum markers for diagnosis and risk stratification in acute coronary syndromes, ed; Cannon CP, Humana Pres, NJ, 1999:147- 71.

5. American Heart Association: Heart and stroke facts:1996. Statistical supplement Dallas, American Heart Association 1996:1-3.

6. Vatner SF, Baig H, Manders WT, Maroko PR. Effect of coronary artery reperfusion on myocardial infarct size calculated from creatinine kinase. J Clin Invest 1978; 61: 104856.

7. Schaap FG, Binas B, Danneberg H, van der Vusse GJ, Glatz JF. Impaired long-chain fatty acid utilization by cardiac myocytes isolated from mice lacking the heart-type fatty acid binding protein gene. Circ Res 1999; 85:329-37.

8. Glatz JFC, van der Vusse GJ, Simoons ML et al. Fatty acid binding protein and the early detection of acute myocardial infarction .Clin Chim Acta 1998; 272:87-92.

9. Van Nieuwenhoven FA, Kleine AH, Wodzig WH, et al. Discrimination between myocardial and skeletal muscle injury by assesment of the plasma ratio of myoglobin over fatty acid binding protein. Circulation 1995; 92:2848-54.

10. Braunwald E, Mark DB, Jones RH, et al. Unstable Angina: Diagnosis and management.Clinical practice guideline No. 10 (amended). AHCPR publication No: 94-0602. Rockville, MD: Agency for health service, U.S. Department of Health and Human services; 1994.

11. Glatz JF, Van Bilsen M, Paulussen RJ, et al. Release of fatty acid binding protein from isolated rat heart subjected to ischemia and reperfusion or to the calcium paradox.Biochim Biophys Acta.1988;961:148- 52.

12. Glatz JF, Van Der Vusse GJ, Maessen JG, et al. Fatty acidbinding protein as a marker of muscle injury: experimental finding and clinical application. Acta Anaestesiol Scand Suppl. 1997; 111: 292-4.

13. Ishii J, Wang JH, Naruse $H$, et al. Serum concentration of myoglobin vs human heart-type cytoplasmic fatty acid binding protein in early detection of acute myocardial infarction. Clin Chem 1997; 43:1372-8. 
14. Gibbons RJ, Antman EM, et al. ACC/AHA 2002 Guideline update for the management of patients with unstable angina and non-ST segment elevation myocardial infarction -Summary article. A report of the American college of Cardiology/American Heart Association Task Force on Practice Guidelines. J Am Coll Cardiol 2002; 40:1366-74.

15. Bertrand ME, Simoons ML, et al. Management of acute coronary syndromes in patients presenting without persistent ST-segment elevation. The task force on the management of acute coronary syndromes of the European Society of Cardiology. Euro Heart J 2002; 23: 1809- 40.

16. American Heart Association. Heart disease and stroke statistics-2004 Update. Dallas, TX: American Heart Association; 2003.

17. 2006 Heart and Stroke statistics for women. American heart association heart disease and stroke statistics-2006 update.

18. Onat A, Sansoy V, Soydan, et al. TEKHARF ;12 ylllk izleme deneyimine göre Türk erişkinlerinde kalp sağlığı. Argos iletişim hizmetleri reklamcılık ve ticaret anonim şirketi. Temmuz İstanbul, 2003.

19. Cavus U, et al. Heart type fatty acid binding protein can be a diagnostic marker in acute coronary syndromes. Journal of the National Medical Association et on 2006; 98(7): 1067-70.

20. Abe S, Saigo M, Yamashita T, et al. Heart fatty acid binding protein is a useful in the early and myocard-specific diagnosis of acute myocardial infarction. Circulataion 1996; 94:I-323 (abstract)

21. Tanaka T, Hirota Y, Sohmiya K, et al.Serum and urinary human heart fatty acid binding protein in acute myocardial ischemia. Clin Biochem 1991;24:195-201.

22. Wodzig KWH,Kragten JA, Hermens WT, Glatz JFC, Van Dieijen-Visser MP. Estimation of myocardial infarct size from plasma myoglobin or fatty acid binding protein. Influence of renal function. Eur J Chem Clin Biochem 1997; 35: 191-8.

23. Mair J, Artner-Dworzak E, Lechleitner P, et al. Cardiac troponin $\mathrm{T}$ in diagnosis of acute myocardial infarction. Clin Chem 1991; 37: 845-52.

24. Keffer JH. Myocardial markers of injury evolution and insights. Am J Clin Pathol 1996; 105: 305-20.

25. Seino Y, Ogata K, Takano T, et al. Use of whole blood rapid panel test for heart type fatty acid binding protein in patients with acute chest pain: comparison with troponin- $T$ and myoglobin test. Am J Med 2003; 115: 185-90. 